\title{
Macro news and bond yield spreads in the euro area
}

\section{Guglielmo Maria Caporale, Fabio Spagnolo \& Nicola Spagnolo}

To cite this article: Guglielmo Maria Caporale, Fabio Spagnolo \& Nicola Spagnolo (2017): Macro news and bond yield spreads in the euro area, The European Journal of Finance, DOI: 10.1080/1351847X.2017.1285797

To link to this article: http://dx.doi.org/10.1080/1351847X.2017.1285797

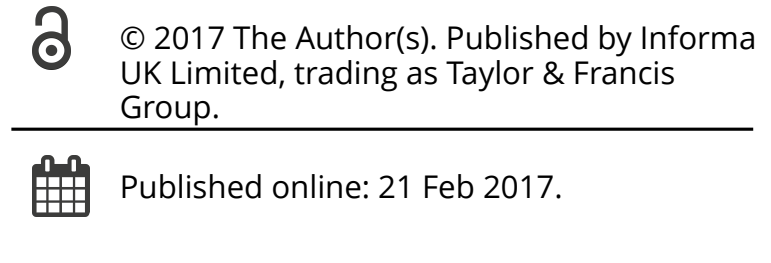

Submit your article to this journal $\sqsubset$

\section{Џ Article views: 96}

Q View related articles $\square$

View Crossmark data $ऍ$ 


\title{
Macro news and bond yield spreads in the euro area
}

\author{
Guglielmo Maria Caporale ${ }^{\mathrm{a} *}$, Fabio Spagnolo ${ }^{\mathrm{a}}$ and Nicola Spagnolo ${ }^{\mathrm{a}, \mathrm{b}}$ \\ ${ }^{a}$ Department of Economics and Finance, Brunel University, London, UK; ${ }^{b}$ Centre for Applied Macroeconomic Analysis \\ (CAMA), Australian National University, Canberra, Australia
}

(Received 25 May 2016; final version received 16 January 2017)

\begin{abstract}
This paper analyses the effects of newspaper coverage of macro news on the spread between the yield on the 10-year German Bund and on sovereign bonds in eight countries belonging to the euro area (Belgium, France, Greece, Ireland, Italy, the Netherlands, Portugal and Spain) using daily data for the period 1999-2014. The econometric analysis is based on the estimation of a VAR-GARCH model. The results can be summarized as follows. Negative news have significant positive effects on yield spreads in all GIIPS (Greece, Ireland, Italy, Portugal and Spain) countries but Italy before September 2008 ; markets respond more to negative news, and their reaction has increased during the recent financial crisis. News volatility has a significant impact on yield spread volatility, the effects being more pronounced in the case of negative news and bigger in the most recent crisis period, especially in the GIIPS countries. Further, the conditional correlations between yield spreads and negative news increase in absolute value during the financial crisis (especially in the GIIPS countries), indicating a higher sensitivity of the former to the latter.
\end{abstract}

Keywords: newspapers news; VAR-GARCH model; volatility spillovers; yield spreads

JEL Classification: C32; F36; G15

\section{Introduction}

The recent European sovereign debt crisis has generated a lot of interest in the effects of macroeconomic news on financial markets. The crisis started in September 2009, when the Greek public deficit turned out to be considerably higher than originally forecast, and then quickly spread to the group of countries now collectively known as GIIPS (Greece, Ireland, Italy, Portugal and Spain), and led to the creation of the European Financial Stabilization Mechanism and the European Financial Stability Facility in an attempt to deal with fiscal solvency in these countries.

Since interest rates are forward-looking, and under the efficient market hypothesis, only unanticipated news should affect asset prices. In the case of a bond, the price equals the present value of all expected future cash flows from the asset discounted at an appropriate rate. According to the Fisher hypothesis, the corresponding yield can be decomposed into a real interest rate and an expected inflation component, both conditional on the available information set. A news release represents a change in the information set which can affect the yield on (and therefore the price of) the bond. Various empirical studies have been carried out for the US bond markets. For instance, Gürkaynak, Sack and Swanson (2005) provide evidence that long-term interest rates respond to the unexpected component of macro news releases and monetary policy announcements; in their opinion, an explicit inflation target would therefore be useful to stabilize inflation

\footnotetext{
*Corresponding author. Email: guglielmo-maria.caporale@brunel.ac.uk
} 
expectations. Papers using high-frequency data include Balduzzi, Elton, and Green (2001) and Andersen et al. (2005), both finding a significant impact of news on US Treasury bond futures contracts; related studies are those by Brenner, Pasquariello, and Subrahmanyam (2009), who report that US news releases increase conditional bond return volatility, and Jiang, Lo, and Valente (2013), who find that trades and orders increase after macro announcements. However, since daily price changes are the sum of intra-day changes, the effect should also be significant at the daily frequency. For instance, Liebermann (2011) finds an impact, especially of soft (i.e. survey-based variables) rather than hard data (nominal and real variables) on US nominal Treasury bond yields at this frequency. Altavilla, Giannone, and Modugno (2013) report that announcements explain a larger percentage of bond yield fluctuations at the quarterly than the daily frequency, which suggests that macro news have a persistent effect on bond yields.

For the emerging economies, Andritzky, Bannister, and Tamirisa (2005) find evidence that bond markets respond mainly to announcements of changes in international ratings; Robitaille and Roush (2006) report that FOMCs leading to higher US interest rates also increase Brazil's bond spre ad. A few studies analyse corporate bonds as well: for instance, Huang and Kong (2007) provide evidence that macro announcements mainly affect high-yield corporate bonds.

The effects of news surprises could depend on their interpretation by the press read by agents; for this reason, Birz and Lott (2011) use newspaper headlines and find that news on GDP and unemployment affect stock returns in the US. Clearly, investor psychology could be crucial to explain the relationship between news and financial markets. For instance, in the model by De et al. (1990) noise traders react to negative belief shocks by selling shares to rational arbitrageurs (see also Campbell, Grossman, and Wang 1993). Coval and Shumway (2001) and Antweiler and Frank (2004) instead relate investor sentiment to trading costs, with the perception of a more negative outlook resulting in lower trading volumes. Tetlock (2007) examines the links between media 'pessimism' (generated by 'bad news') and low investor sentiment in the US by estimating a VAR model. His empirical result suggests that models of noise and liquidity traders can account for the effects of low investor sentiment on financial markets (see also Tetlock, Saar-Tsechansky, and Macskassy 2008; Caporale, Spagnolo, and Spagnolo 2016). Fang and Peress (2009) use a wider dataset including more US daily newspapers and a cross-section of countries and find that media coverage affects asset prices by disseminating information broadly, even if it does not represent news.

Only a few papers have focused on euro member states. Andersson, Hansen, and Sebestyen (2006) analyse intra-day data on German Bund futures over the period 1999-2005 and conclude that these react more strongly to US than to domestic and euro area news releases. A more comprehensive recent study by Beetsma et al. (2013) examines the effects of news on interest rate spreads vis-à-vis Germany in various countries belonging to the euro area. ${ }^{1}$ The news variable is taken from the news-flash of Eurointelligence, an Internet-based service. The analysis is conducted for both 5- and 10-year bonds and uses pooled least squares. The results suggest that more news normally increases the spread in the GIIPS countries, and that the effects are stronger for bad news and during the debt crisis period; further, the size of the spillovers is related to cross-border bank holdings, and consequently these are stronger among GIIPS countries.

Boffelli and Urga (2015) investigated the impact of macro announcements, government bond auctions and rating actions on the 10-year government bond spreads for five European markets with respect to Germany; they identified the impact of three drivers via jump and co-jump detection procedures. De Grauwe and Ji (2013) tested the hypothesis that government bond markets in the Eurozone are more fragile and more susceptible to self-fulfilling liquidity crises than in 
stand-alone countries; they found evidence that a significant part of the surge in the spreads of the peripheral Eurozone countries during 2010-2011 was not connected to underlying increases in the debt-to-GDP ratios and/or other fiscal variables, and instead reflected negative self-fulfilling market sentiments that became very strong from the end of 2010. Saka, Fuertes, and Klotychou (2015) further investigated this issue and tested the De Grauwe and Ji's (2013) Eurozone fragility hypothesis; they found that the perceived commonality in default risk among peripheral and core Eurozone sovereigns increased after monetary policy announcements, which supports the fragility hypothesis.

The present paper contributes to this literature by estimating a bivariate VAR-GARCH $(1,1)$ model to examine the effects of both positive and negative news on yield spreads vis-à-vis the German Bund, which is used as a benchmark; the analysis is carried out for 10-year sovereign bonds issued by eight EMU countries, namely Belgium, France, Greece, Ireland, Italy, the Netherlands, Portugal and Spain, over the period 04/1/1999-28/3/2014, at a daily frequency. As a robustness check, bivariate models are also estimated to analyse the impact of the difference between negative and positive news indices.

Our study makes a threefold contribution. First, it focuses on the relationship between macro news and bonds before and after the 2008 crisis in the euro area, for which limited evidence is available. Second, in contrast to most existing papers in this area of the literature, who only consider interactions between the first moments, it also models the linkages between the second moments of the variables of interest; the conditional volatility can be seen as a proxy for uncertainty, whose role we are therefore able to assess in this context. Third, it differs from the study by Beetsma et al. (2013) in that it takes a time series approach which is better suited to capturing time variation in the high-frequency series being examined, and considers a considerably longer sample. Furthermore, we are interested in testing the hypothesis that it is not just news surprises (calculated as the difference between the predicted macro indicators and their realized values) that affect the fixed income market, but also the way in which macro news releases are perceived and interpreted by the media.

The layout of the paper is as follows. Section 2 outlines the econometric modelling approach. Section 3 describes the data and presents the empirical findings. Section 4 summarizes the main findings and offers some concluding remarks.

\section{The model}

We represent the first and second moments of yield spreads and news indices using a VAR$\operatorname{GARCH}(1,1)$ process. $^{2}$ In order to account for the possible effects of the 2008 financial crisis, we include a dummy variable (denoted by *) with a switch on 15 September 2008, that is, on the day of the collapse of Lehman Brothers. The second subsample therefore also includes the public debt crisis which started in 2009 but whose seeds can be found in the banking crisis dating back to 2008. In its most general specification, the model takes the following form:

$$
\mathbf{x}_{t}=\boldsymbol{\alpha}+\beta \mathbf{x}_{t-1}+\boldsymbol{\gamma} \mathbf{f}_{t-1}+\mathbf{u}_{t},
$$

where $\mathbf{x}_{t}=\left(\right.$ Spread $_{t}$, PositiveNews $_{t}\left(\right.$ NegativeNews $\left.\left._{t}\right)\right)$ and $\mathbf{x}_{t-1}$ is a corresponding vector of lagged spreads. The data on positive and negative News, as reported by the media, are discussed in the following section. We control for news surprises and financial market shocks by including in the mean equation the Bloomberg News Surprises Index and the VIX: $f_{t-1}=$ (Surprises $_{t-1}$, VIX $\left._{t-1}\right)$. The residual vector $\mathbf{u}_{t}=\left(u_{1, t}, u_{2, t}\right)$ is bivariate and normally distributed 
$\mathbf{u}_{t} \mid I_{t-1} \sim\left(\mathbf{0}, H_{t}\right)$ with its corresponding conditional variance-covariance matrix given by

$$
H_{t}=\left[\begin{array}{ll}
h_{11 t} & h_{12 t} \\
h_{12 t} & h_{22 t}
\end{array}\right] .
$$

The parameter vector of the mean return equation (1) is defined by the constant $\alpha=\left(\alpha_{1}, \alpha_{2}\right)$, and the autoregressive term, $\boldsymbol{\beta}=\left(\beta_{11}, \beta_{12}+\beta_{12}^{*} \mid \beta_{21}, \beta_{22}\right)$, which allows for mean spread effects from positive (negative), $\beta_{12}$, news. Furthermore, $\gamma=\left(\gamma_{11} \mid \gamma_{12}\right)$ is the vector of control parameters, that is, domestic news surprises index and global financial markets uncertainty ${ }^{3}$ that appear in the first equation only. The parameter matrices for the variance equation (2) are defined as $C_{0}$, which is restricted to be upper triangular, and two unrestricted matrices $A_{11}$ and $G_{11}$. Therefore, the second moment ${ }^{4}$ will take the following form:

$$
H_{t}=C_{0}^{\prime} C_{0}+A_{11}^{\prime}\left[\begin{array}{cc}
u_{1, t-1}^{2} & u_{2, t-1} u_{1, t-1} \\
u_{1, t-1} e_{2, t-1} & u_{2, t-1}^{2}
\end{array}\right] A_{11}+G_{11}^{\prime} H_{t-1} G_{11},
$$

where

$$
A_{11}=\left[\begin{array}{cc}
a_{11} & a_{12} \\
a_{21}+a_{21}^{*} & a_{22}
\end{array}\right] ; \quad G_{11}=\left[\begin{array}{cc}
g_{11} & g_{12} \\
g_{21}+g_{21}^{*} & g_{22}
\end{array}\right] .
$$

Equation (3) models the dynamic process of $H_{t}$ as a linear function of its own past values $H_{t-1}$ and past values of the squared innovations $\left(u_{1, t-1}^{2}, u_{2, t-1}^{2}\right)$. The parameters of Equation (3) are given by $C_{0}$, which is restricted to be upper triangular, and the two matrices $A_{11}$ and $G_{11}$. Volatility spillovers (causality-in-variance) from positive (negative) news volatility are captured by $a_{21}$ before and $\left(a_{21}+a_{21}^{*}\right)$ after the crisis, whereas $a_{12}$ measures reverse causality. The BEKK model guarantees by construction that the covariance matrix in the system is positive definite. Furthermore, the conditional correlations between spread and positive (negative) news will be given by

$$
\rho_{12, t}=h_{12, t} / \sqrt{h_{11, t}} \sqrt{h_{22, t}} \text {. }
$$

Given a sample of $T$ observations, a vector of unknown parameters $\theta$ and a $2 \times 1$ vector of variables $\boldsymbol{x}_{t}$, the conditional density function for model (1) is

$$
f\left(\mathbf{x}_{t} \mid I_{t-1} ; \theta\right)=(2 \pi)^{-1}\left|H_{t}\right|^{-1 / 2} \exp \left(-\frac{\mathbf{u}_{t}^{\prime}\left(H_{t}^{-1}\right) \mathbf{u}_{t}}{2}\right) .
$$

The log-likelihood function is

$$
L=\sum_{t=1}^{T} \log f\left(\mathbf{x}_{t} \mid I_{t-1} ; \theta\right)
$$

where $\theta$ is the vector of unknown parameters. The standard errors are calculated using the quasi-maximum likelihood method of Bollerslev and Wooldridge (1992), which is robust to the distribution of the underlying residuals.

\section{Empirical results}

\subsection{Data}

We use daily data (from Bloomberg) for eight countries (Belgium, France, Greece, Ireland, Italy, the Netherlands, Portugal and Spain) belonging to the Eurozone for the period 4/1/1999$28 / 3 / 2014$, for a total of 3808 observations. Daily spreads are defined as the logarithm of the 
difference between 10-year domestic sovereign bond yields and the yield on the German Bund. Furthermore, we control for global financial market shocks by including the VIX index and for news surprises by including the differences between realized macro figures and agents' expectations. Bloomberg is the data source for the (log) change of the VIX index, based on the implied volatility of S\&P 500 stock market index options, news surprises and bond yields. We define daily returns as the logarithmic differences of bond spreads. We consider news coverage of four macroeconomic series, that is, GDP, unemployment, retail sales and durable goods (as in Birz and Lott, 2011). The data for the News Index are also collected from Bloomberg where news coverage is proxied by story headlines counts. News headlines were selected using an extensive search string, containing words indicating articles dealing with macro variables, and also allowing us to distinguish between articles with a 'potentially positive' or 'potentially negative' connotation towards GDP, unemployment, retail sales and durable goods. The index we use does not distinguish between different types of macro news, since the focus of this study is to analyse the effects of positive and negative macro news, respectively, as reported and interpreted by the media. News headlines about unemployment and GDP are the most frequent, whereas there is less coverage of retail sales and durable goods releases. ${ }^{5}$ The daily positive (negative) news index is defined as follows:

$$
\begin{aligned}
\text { Positive (Negative) News Index }= & \ln [\mathrm{e}+\text { domestic positive (negative) news } \\
& + \text { international positive (negative) news }]
\end{aligned}
$$

Both domestic and international (within the euro area) news are used to deal with the issue of national newspaper stories about the status of the economy potentially being politically biased (Birz and Lott, 2011). The descriptive statistics, presented in Table 1, show that on average the number of positive news releases is bigger than that of negative ones, with the exception of Belgium. However, since the onset of the 2008 crisis, negative news releases have become more frequent in all countries but Belgium and the Netherlands. The shift has been particularly marked for the GIIPS countries, that have been hit most severely by the crisis. Furthermore, the average number of stories, either negative or positive, has increased substantially since 2008, with the press capturing the growing interest of investors in the state of the economy: sovereign bonds, regarded as the safest and arguably risk-free investment, have been perceived as a much riskier asset as a result of weak macroeconomic fundamentals.

As for the second moments of the series, in the pre-crisis period negative news exhibit higher volatility than positive ones in all countries but Belgium. Further, uncertainty (as proxied by the conditional volatility) of both types of news shifts upwards in the post-September 2008 period, the only exception being positive news in the case of Ireland. Finally, since 2008 there has been an increase in domestic sovereign bond yield spreads vis-à-vis the German Bund in all cases, particularly for the GIIPS countries, Greece being the most prominent case (Figure 1). This evidence supports the inclusion of a switch dummy in the model specification.

\subsection{Discussion of the results}

In order to test the adequacy of the models, Ljung-Box portmanteau tests were performed on the standardized and squared residuals. Overall, the results indicate that the VAR-GARCH $(1,1)$ specification captures satisfactorily the persistence in spreads and squared spreads in all cases. Causality effects in the conditional mean and variance vary in magnitude and sign across countries. Note that the sign of the coefficients on cross-market volatilities cannot be determined. 
Table 1. Descriptive statistics.

\begin{tabular}{|c|c|c|c|c|c|c|c|c|c|c|}
\hline & \multicolumn{5}{|c|}{ Pre 2008} & \multicolumn{5}{|c|}{ Post 2008} \\
\hline & Mean & SD & Skew. & Kur. & JB & Mean & SD & Skew. & Kur. & JB \\
\hline \multicolumn{11}{|c|}{10 yrs bond spreads vis-à-vis German Bund } \\
\hline Belgium & 0.17 & 0.14 & 1.03 & 4.21 & 580 & 0.99 & 0.55 & 1.50 & 5.13 & 784 \\
\hline France & 0.08 & 0.07 & 1.25 & 5.39 & 1214 & 0.57 & 0.30 & 1.40 & 4.64 & 609 \\
\hline Greece & 0.41 & 0.35 & 2.13 & 7.82 & 4204 & 10.89 & 9.08 & 1.34 & 4.28 & 511 \\
\hline Ireland & 0.07 & 0.16 & 1.63 & 9.70 & 5624 & 3.53 & 2.06 & 0.81 & 2.72 & 157 \\
\hline Italy & 0.27 & 0.15 & 3.01 & 16.94 & 2336 & 2.26 & 1.23 & 0.54 & 2.22 & 103 \\
\hline Netherlands & 0.09 & 0.08 & 1.33 & 7.71 & 2966 & 0.34 & 0.13 & 0.94 & 3.48 & 218 \\
\hline Portugal & 0.21 & 0.15 & 0.91 & 4.69 & 623 & 4.79 & 3.31 & 0.54 & 2.27 & 98 \\
\hline \multirow[t]{2}{*}{ Spain } & 0.13 & 0.14 & 1.03 & 4.21 & 582 & 2.41 & 1.36 & 0.34 & 2.31 & 54 \\
\hline & Mean & SD & & Min & Max & Mean & SD & & Min & Max \\
\hline \multicolumn{11}{|l|}{ Positive news } \\
\hline Belgium & 0.06 & 0.43 & & 0 & 9 & 0.41 & 3.91 & & 0 & 102 \\
\hline France & 0.38 & 0.81 & & 0 & 9 & 1.27 & 5.14 & & 0 & 104 \\
\hline Greece & 0.02 & 0.04 & & 0 & 2 & 1.07 & 5.74 & & 0 & 91 \\
\hline Ireland & 0.02 & 0.07 & & 0 & 2 & 0.38 & 1.92 & & 0 & 57 \\
\hline Italy & 0.26 & 0.34 & & 0 & 6 & 0.68 & 4.38 & & 0 & 77 \\
\hline Netherlands & 0.06 & 0.31 & & 0 & 5 & 0.47 & 3.20 & & 0 & 74 \\
\hline Portugal & 0.03 & 0.06 & & 0 & 2 & 0.46 & 3.18 & & 0 & 74 \\
\hline Spain & 0.09 & 0.15 & & 0 & 4 & 0.71 & 4.64 & & 0 & 77 \\
\hline \multicolumn{11}{|c|}{ Negative news } \\
\hline Belgium & 0.08 & 0.39 & & 0 & 7 & 0.26 & 2.73 & & 0 & 98 \\
\hline France & 0.28 & 1.26 & & 0 & 18 & 1.49 & 3.83 & & 0 & 101 \\
\hline Greece & 0.01 & 0.25 & & 0 & 5 & 1.42 & 4.26 & & 0 & 106 \\
\hline Ireland & 0.01 & 0.26 & & 0 & 4 & 0.67 & 3.31 & & 0 & 102 \\
\hline Italy & 0.05 & 0.91 & & 0 & 9 & 0.83 & 3.41 & & 0 & 108 \\
\hline Netherlands & 0.05 & 0.45 & & 0 & 8 & 0.15 & 1.03 & & 0 & 25 \\
\hline Portugal & 0.01 & 0.31 & & 0 & 7 & 0.61 & 2.73 & & 0 & 77 \\
\hline Spain & 0.01 & 0.48 & & 0 & 8 & 1.11 & 3.66 & & 0 & 104 \\
\hline
\end{tabular}

Notes: Daily spreads are the difference between domestic 10 years bonds and the 10 years German Bund. News counts refer to domestic and international (within the Euroarea) media coverage. Note that descriptive statistics refer to raw daily data (story counts). The sample size covers the period 04/1/1999-28/3/2014, for a total of 3808 observations.

The estimates of the parameters of the VAR-GARCH(1,1) model as well as the associated robust standard errors and likelihood function values are presented in Tables A1-A8. The results are summarized in Table 2. We select the optimal lag length of the mean equation using the Schwarz information criterion.

We test for mean and volatility spillovers by placing restrictions on the relevant parameters; in particular, the following null hypotheses are tested: (i) positive (negative) news affect the spreads before the 2008 crisis $\left(\beta_{12}=0\right.$ ); (ii) positive (negative) news affect the spreads after the 2008 crisis $\left(\beta_{12}^{*}=0\right)$; (iii) positive (negative) news volatility affects spreads volatility before the 2008 crisis $\left(a_{21}=g_{21}=0\right)$; and finally (iv) positive (negative) news volatility affects spreads volatility after the 2008 crisis $\left(a_{21}^{*}=g_{21}^{*}=0\right){ }^{6}$

The following points are noteworthy. Concerning the effects of negative news on bond spreads $\left(\beta_{12}\right)$, we find positive and significant causality at the standard 5\% significance level for France, 
Belgium
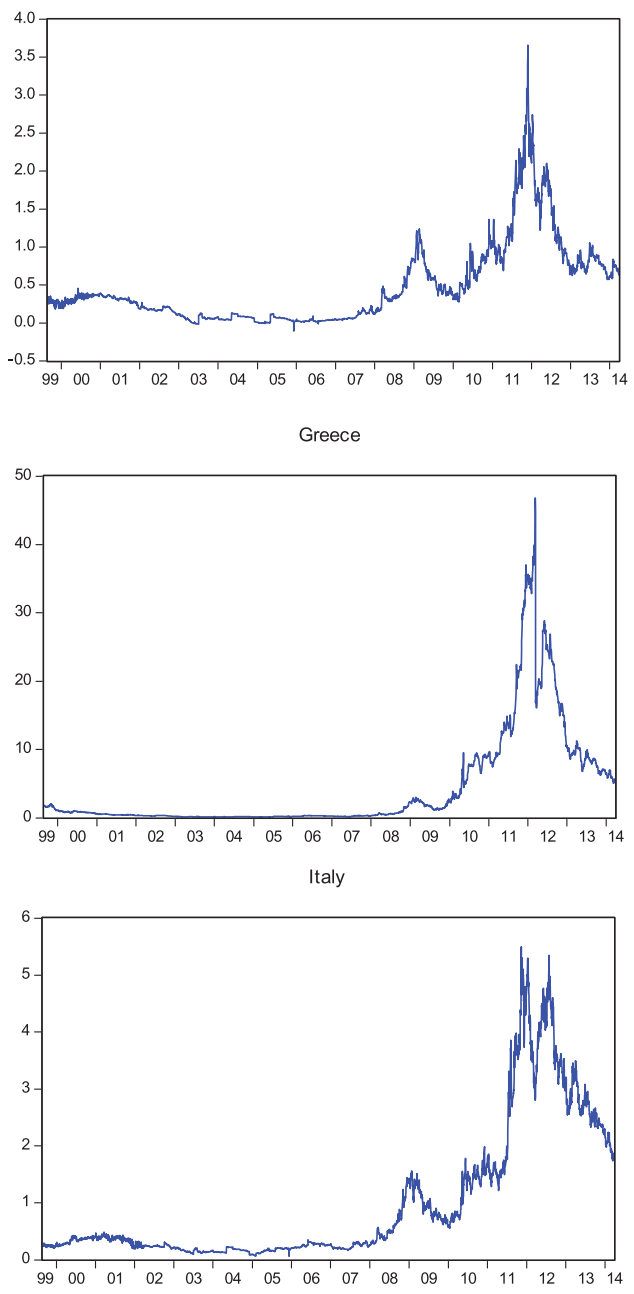

Portugal

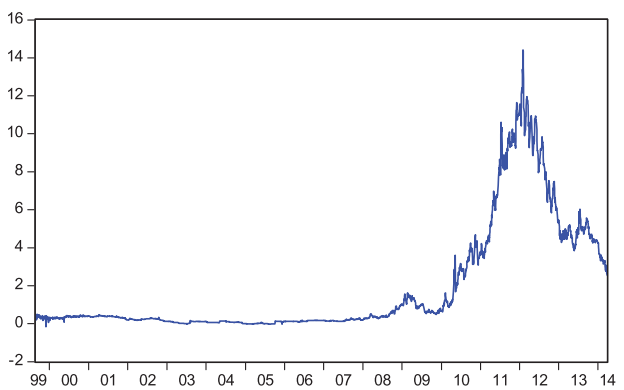

France
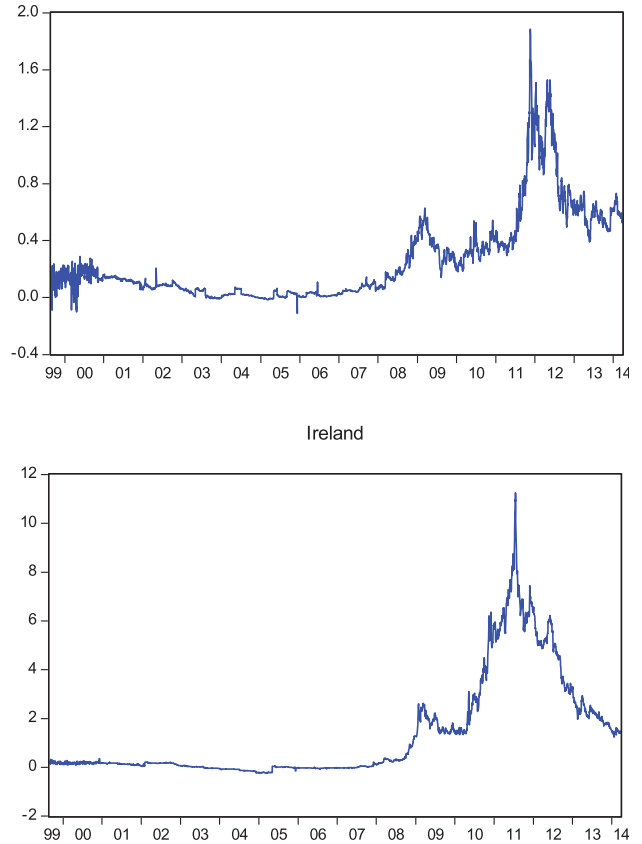

Netherlands

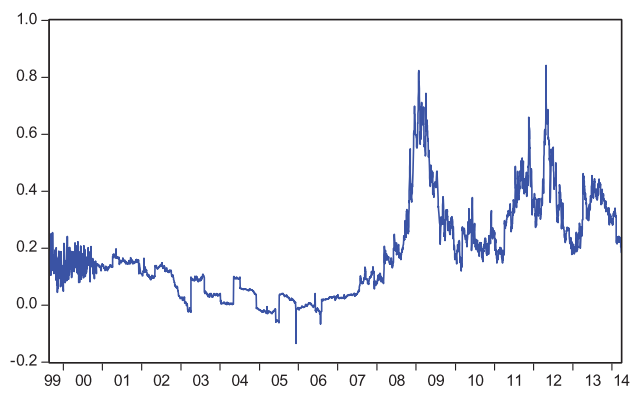

Spain

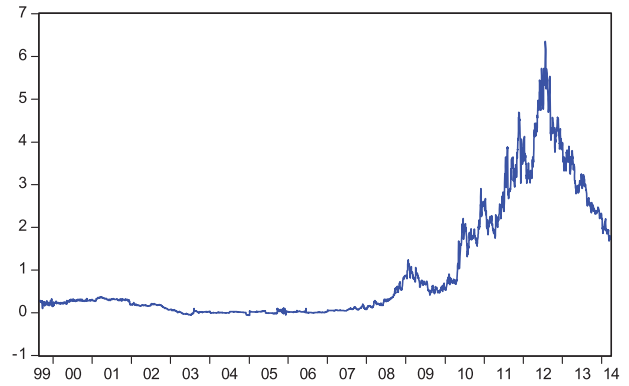

Figure 1. Domestic 10 years bond spread vs. German Bund. 
Table 2. Summary results for conditional mean (Equation (1)) and conditional variance (Equation (3)) equations.

\begin{tabular}{|c|c|c|c|c|c|c|}
\hline & \multicolumn{3}{|c|}{ Pre 2008} & \multicolumn{3}{|c|}{ Post 2008} \\
\hline & Negative & Positive & Neg-Pos & Negative & Positive & Neg-Pos \\
\hline \multicolumn{7}{|c|}{ Mean spillovers between bond spread and news } \\
\hline Belgium & & & & $\mathrm{x}$ & & \\
\hline France & $\mathrm{x}$ & $\mathrm{x}$ & $\mathrm{x}$ & $\mathrm{x}$ & & $\mathrm{x}$ \\
\hline Greece & $\mathrm{x}$ & & $\mathrm{x}$ & $\mathrm{x}$ & & $\mathrm{x}$ \\
\hline Ireland & $\mathrm{x}$ & & & $\mathrm{x}$ & & $\mathrm{x}$ \\
\hline Italy & & $\mathrm{x}$ & & $\mathrm{x}$ & & $\mathrm{x}$ \\
\hline Netherlands & & $\mathrm{x}$ & & $\mathrm{x}$ & & \\
\hline Portugal & $\mathrm{x}$ & $\mathrm{x}$ & & $\mathrm{x}$ & & $\mathrm{x}$ \\
\hline Spain & $\mathrm{x}$ & & & $\mathrm{x}$ & & $\mathrm{x}$ \\
\hline \multicolumn{7}{|c|}{ Causality in variance spillovers between bond spread and news } \\
\hline Belgium & $\mathrm{x}$ & $\mathrm{x}$ & & $\mathrm{x}$ & $\mathrm{x}$ & \\
\hline France & & $\mathrm{x}$ & $\mathrm{x}$ & & $\mathrm{x}$ & $\mathrm{x}$ \\
\hline Greece & $\mathrm{x}$ & $\mathrm{x}$ & $\mathrm{x}$ & $\mathrm{x}$ & $\mathrm{x}$ & $\mathrm{x}$ \\
\hline Ireland & $\mathrm{x}$ & $\mathrm{x}$ & $\mathrm{x}$ & $\mathrm{x}$ & $\mathrm{x}$ & $\mathrm{x}$ \\
\hline Italy & $\mathrm{x}$ & $\mathrm{x}$ & $\mathrm{x}$ & $\mathrm{x}$ & $\mathrm{x}$ & $\mathrm{x}$ \\
\hline Netherlands & $\mathrm{x}$ & $\mathrm{x}$ & $\mathrm{x}$ & $\mathrm{x}$ & $\mathrm{x}$ & $\mathrm{x}$ \\
\hline Portugal & $\mathrm{x}$ & $\mathrm{x}$ & $\mathrm{x}$ & $\mathrm{x}$ & $\mathrm{x}$ & $\mathrm{x}$ \\
\hline Spain & $\mathrm{x}$ & $\mathrm{x}$ & $\mathrm{x}$ & $\mathrm{x}$ & $\mathrm{x}$ & $\mathrm{x}$ \\
\hline
\end{tabular}

Greece, Ireland and Portugal. ${ }^{7}$ The biggest estimated coefficients are those for Ireland and Portugal, with values equal to 0.7344 and 0.7345 , respectively. The post-September 2008 results indicate the presence of significant causality effects at the standard 5\% significance level for all eight countries. The estimated coefficients $\left(\beta_{12}^{*}\right)$ are particularly high for Greece, Ireland, Italy, Portugal and Spain with values equal to 6.6801,0.8816,1.7216,4.2016 and 2.1916, respectively. In the case of Greece, the estimate of the parameter measuring the causality effect is one hundred times bigger in the second subsample. Overall, these results are in line with those reported by Beetsma et al. (2013).

As for the effects of positive news on yield spreads, there appears to be negative and significant causality at the standard 5\% significance level only for France, Italy, the Netherlands and Portugal. The largest coefficient (in absolute value) is the one for the Netherlands $(-0.0792)$. The post-September 2008 results imply no significant spillover effect for any country. Overall, we find that negative news have bigger effects (in absolute value) than positive news in all countries considered. This pattern has been reinforced by the recent crisis. The implication of these findings is that the media have been playing an increasing role in shaping agents' investment strategies through their interpretation of economic news. This is particularly true of periods of economic/financial turbulence, when news headlines are more likely to focus on the latest economic and financial developments.

The nature of the model allows us to control and test for the presence of reverse causality $\left(\beta_{21}\right)$, that is, the effects of bond spread behaviour on the number of positive and negative news stories, but we do not find any statistically significant evidence for it. ${ }^{8}$

Similar to Birz and Lott (2011), we also find in all cases that news surprises are not statistically significant. This is not particularly surprising if one considers the fact that news are released on a very small percentage of trading days, in contrast to newspaper coverage which is daily, and 
Belgium

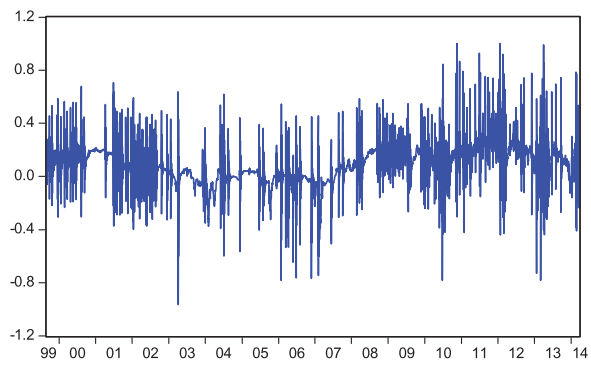

Greece

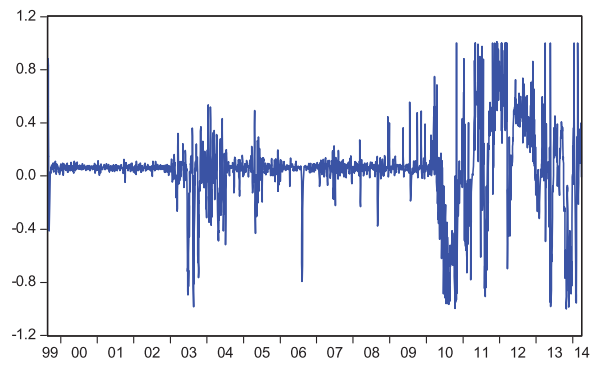

Ireland

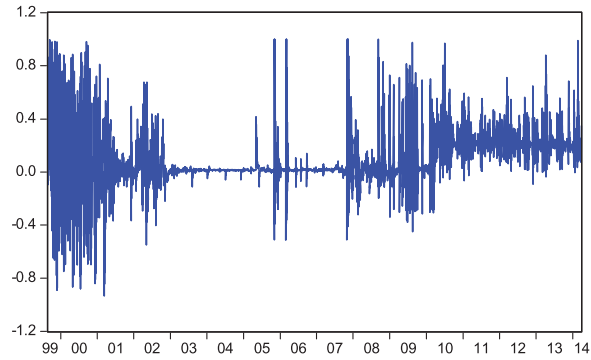

Portugal

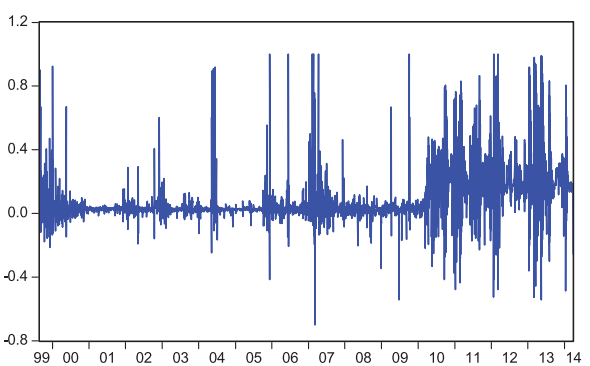

France

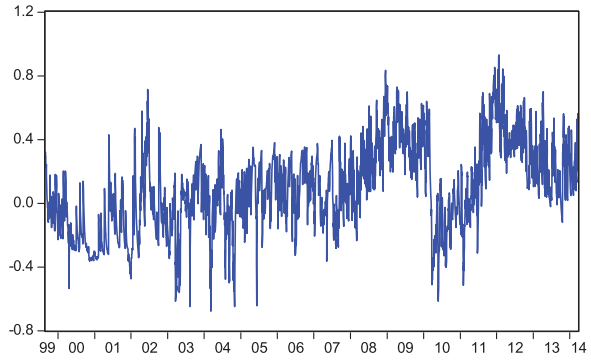

Netherlands

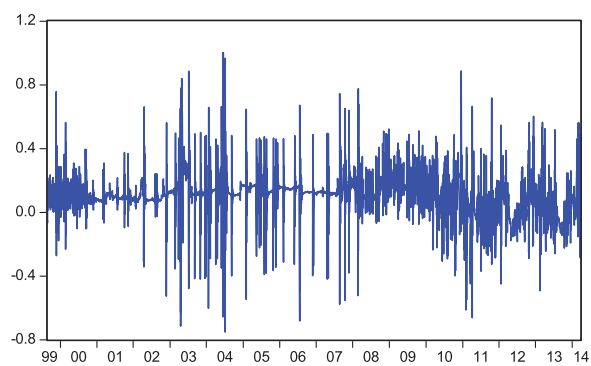

Italy

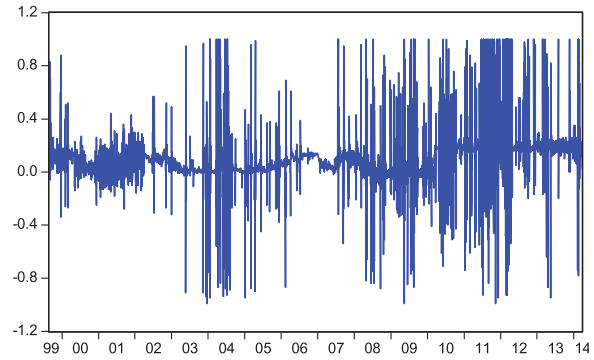

Spain

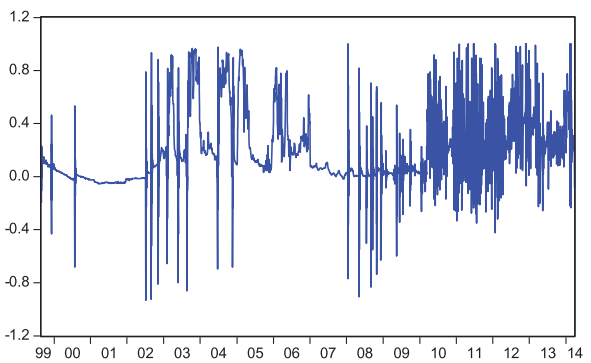

Figure 2. VAR-GARCH $(1,1)$ conditional correlations between bond spreads and Negative News Index. 
therefore can only have a very limited impact. ${ }^{9}$ On the contrary, the VIX is found to be highly significant in all cases, which suggests that uncertainty in the US stock market (a proxy for global instability) tends to widen the spread.

Concerning the conditional variance equations, the estimated 'own-market' coefficients are statistically significant and the estimates of $g_{11}$ suggest a rather high degree of persistence. The estimates suggest that positive and negative news volatility has a significant impact on yield spread volatility (note that the sign cannot be established), with the exception of negative news in France. This is what one would expect: more uncertainty about the real economy makes it more difficult for agents to decide on their investment strategies. The magnitude of the causality effect (measured by $a_{21}$ ) is bigger (in absolute value) for negative than for positive news volatility in all countries examined but France. Furthermore, there is evidence of the 2008 crisis affecting the causality-in-variance dynamics. In particular, the post-crisis negative news volatility effect substantially increased at least for the GIIPS countries, especially in Greece and Portugal, with $\left(a_{21}+a_{21}^{*}\right)$ being equal to 0.0679 and 0.1482 , respectively, compared to the pre-September 2008 period, when the corresponding values were 0.0291 and 0.0677 . Also, the estimated coefficients on the exogenous variables suggest that in most cases news surprises $\left(\gamma_{11}\right)$ are not significant, consistently with Birz and Lott (2011), ${ }^{10}$ whereas the VIX $\left(\gamma_{22}\right)$ is found to be significant and with the expected positive sign, indicating that a higher level of uncertainty leads to a wider yield spread.

Table 3. Conditional correlations summary.

\begin{tabular}{|c|c|c|c|c|c|c|}
\hline & \multicolumn{3}{|c|}{ Pre 2008} & \multicolumn{3}{|c|}{ Post 2008} \\
\hline & Mean & SD & Test & Mean & SD & Test \\
\hline \multicolumn{7}{|l|}{ Panel A } \\
\hline \multicolumn{7}{|c|}{ Bond spreads and Negative News Index } \\
\hline Belgium & 0.0632 & 0.1605 & $32.45^{\mathrm{a}}$ & 0.1652 & 0.1956 & $28.77^{\mathrm{a}}$ \\
\hline France & 0.0612 & 0.2512 & $23.16^{\mathrm{a}}$ & 0.1912 & 0.2723 & $35.67^{\mathrm{a}}$ \\
\hline Greece & 0.0432 & 0.1235 & $19.67^{\mathrm{a}}$ & 0.0534 & 0.4732 & $42.29^{\mathrm{a}}$ \\
\hline Ireland & 0.0415 & 0.2216 & $44.41^{\mathrm{a}}$ & 0.2365 & 0.1231 & $29.75^{\mathrm{a}}$ \\
\hline Italy & 0.0542 & 0.1861 & $41.98^{\mathrm{a}}$ & 0.1954 & 0.3013 & $28.97^{\mathrm{a}}$ \\
\hline Netherlands & 0.1601 & 0.1301 & $37.65^{\mathrm{a}}$ & 0.0398 & 0.1707 & $30.16^{\mathrm{a}}$ \\
\hline Portugal & 0.0433 & 0.0922 & $29.88^{a}$ & 0.2044 & 0.2272 & $45.31^{\mathrm{a}}$ \\
\hline Spain & 0.1511 & 0.2632 & $27.98^{\mathrm{a}}$ & 0.2911 & 0.2354 & $27.91^{\mathrm{a}}$ \\
\hline Panel B & & & & & & \\
\hline \multicolumn{7}{|c|}{ Bond spreads and (Negative - Positive) News Index } \\
\hline Belgium & 0.0012 & 0.1313 & $32.78^{\mathrm{a}}$ & 0.0476 & 0.1472 & $30.87^{\mathrm{a}}$ \\
\hline France & 0.0001 & 0.2151 & $35.11^{\mathrm{a}}$ & 0.0353 & 0.2317 & $32.88^{\mathrm{a}}$ \\
\hline Greece & 0.0501 & 0.0925 & $39.09^{\mathrm{a}}$ & 0.1212 & 0.1291 & $54.67^{\mathrm{a}}$ \\
\hline Ireland & 0.0302 & 0.1041 & $40.12^{\mathrm{a}}$ & 0.1221 & 0.1283 & $53.22^{\mathrm{a}}$ \\
\hline Italy & 0.0121 & 0.1773 & $36.43^{\mathrm{a}}$ & 0.1231 & 0.1851 & $49.76^{\mathrm{a}}$ \\
\hline Netherlands & -0.1012 & 0.2659 & $24.34^{\mathrm{a}}$ & -0.1002 & 0.2032 & $24.22^{\mathrm{a}}$ \\
\hline Portugal & 0.0121 & 0.1263 & $28.55^{\mathrm{a}}$ & 0.1713 & 0.1810 & $39.68^{\mathrm{a}}$ \\
\hline Spain & 0.0122 & 0.1306 & $40.87^{\mathrm{a}}$ & 0.2542 & 0.2051 & $41.56^{\mathrm{a}}$ \\
\hline
\end{tabular}

Note: Conditional correlations between bond spreads and negative index news (Panel A) and bond spreads and (negative - positive) index news (Panel B) are given by $\rho_{12, t}=h_{12, t} / \sqrt{h}_{11, t} \sqrt{h_{22, t}}$. The null hypothesis of a constant correlation is tested against the alternative of time variation by means of the Engle and Sheppard test (2001). The test results are reported in the column 'Test'. 'Stands for a rejection of the null. 
Belgium
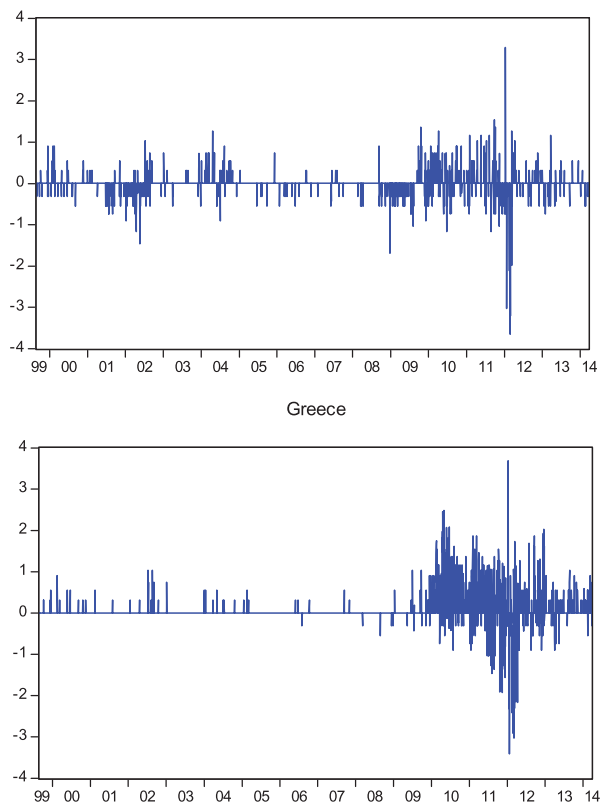

Italy
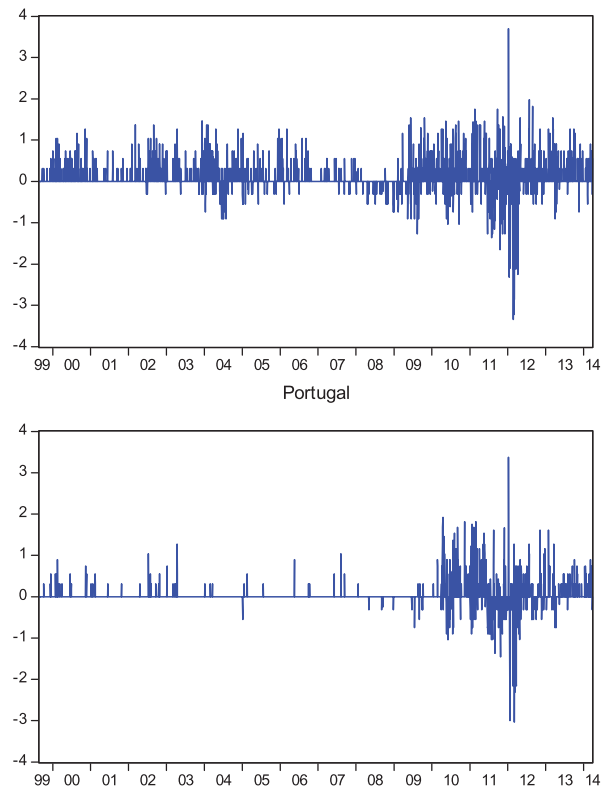

France

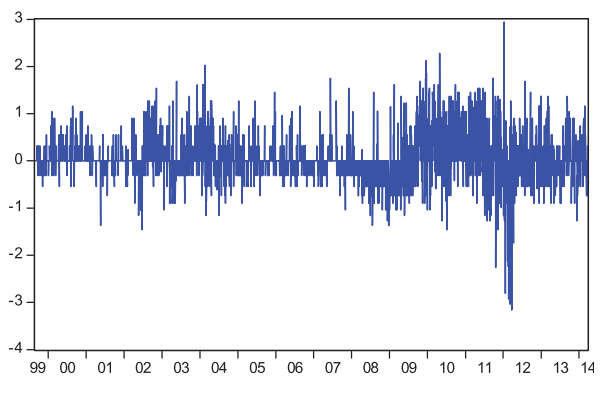

Ireland
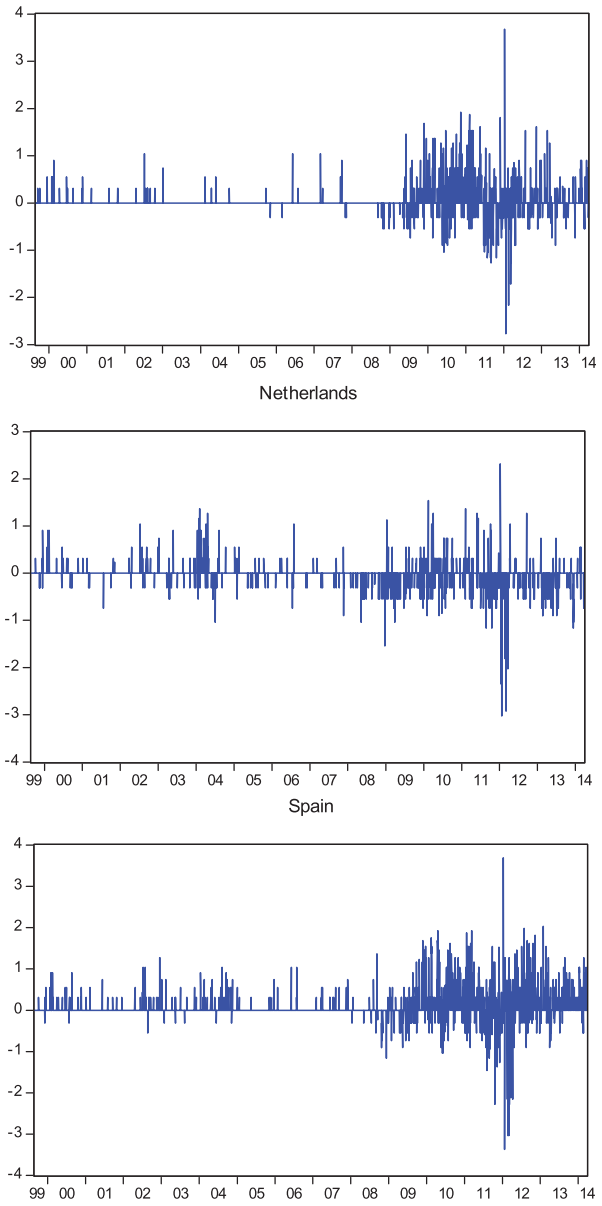

Figure 3. Difference between Negative and Positive News Index. The number of positive (negative) newspaper headlines index is defined as follows: Positive(Negative)NewsIndex $=\ln [e+$ domesticpositive(negative)news + internationalpositive(negative)news $]$. 
Belgium

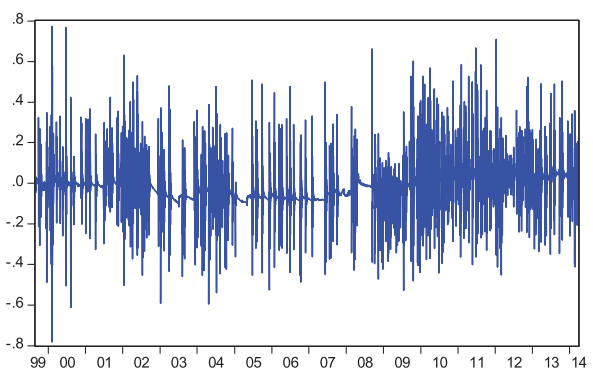

Greece

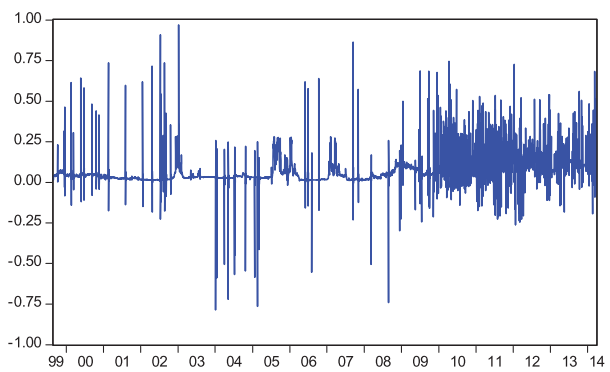

Italy
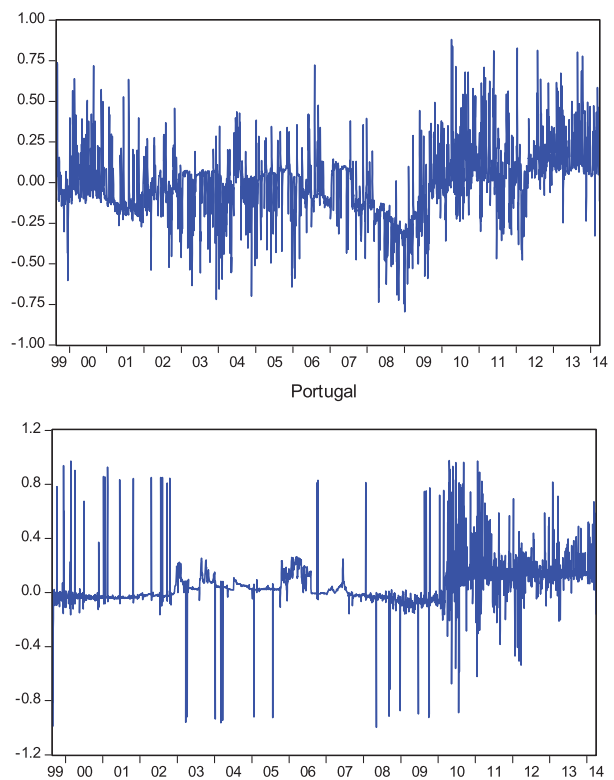

France

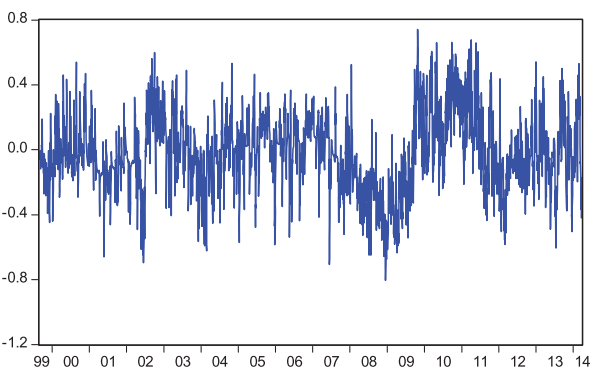

Ireland

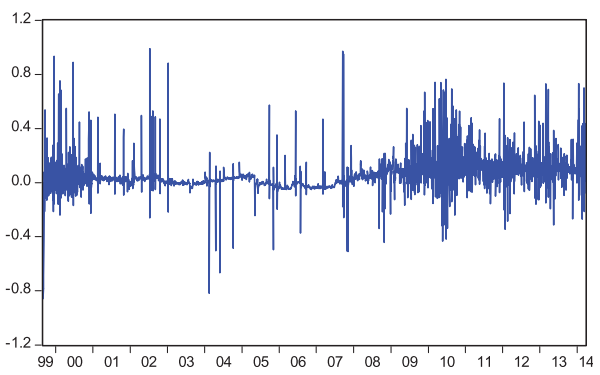

Netherlands
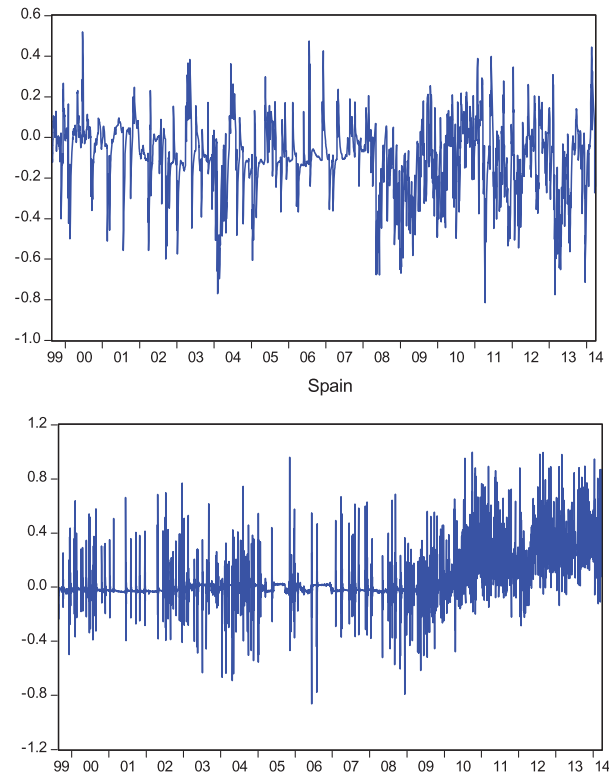

Figure 4. VAR-GARCH(1,1) Conditional Correlations between Bond Spreads and (Negative - Positive) News Index. 
Finally, there is also evidence of co-movement between yield spreads and the news index, as shown by the conditional correlations obtained from the $\operatorname{VAR}-\operatorname{GARCH}(1,1)$ model (Figure 2). In particular, the conditional correlations between negative news and yield spreads are generally positive (on average). ${ }^{11}$

The upward shift in pairwise correlations (between yield spreads and negative news) is quite evident for the GIIPS countries after 2008, especially in the case of Ireland and Portugal, which suggests that bond markets in economies under pressure were particularly sensitive to negative news. Summary (mean and variance) statistics for the conditional correlations, pre- and postSeptember 2008, are reported in Table 3 (Panel A). The means are positive for all eight countries pre-September 2008. Interestingly, in the second subsample conditional correlations have substantially higher mean values (with the exception of the Netherlands), especially in the case of the GIIPS countries, where they at least doubled.

\subsection{Robustness check}

To check robustness (Birz and Lott, 2011) we also consider the difference between negative and positive news indices (Figure 3). The causality-in-mean effect of news is significant especially after September 2008, except for Belgium and the Netherlands, whereas the causality-in-variance spillovers are found to be significant in both sub-periods, with the exception of Belgium, although they are bigger in the post-September 2008 one. The conditional correlations (see Figure 4 and Table 3) are clearly time varying as confirmed by the test statistics under the null hypothesis of constant correlations; they are positive (on average) for all countries but the Netherlands in the post-September 2008 period, with higher values for the GIIPS countries. In the first subperiod, the mean value of the correlations is negative in the case of the Netherlands, although it has the highest standard deviation. These findings corroborate the previous evidence in terms of both co-movements and spillovers effects, although the estimated values are different at times. The Netherlands stands apart in terms of causality patterns and contemporaneous dynamics and would need further investigation.

\section{Conclusions}

This paper has analysed the effects of macro news on the spread between the yield on the 10-year German Bund and on sovereign bonds in eight countries belonging to the euro area (Belgium, France, Greece, Ireland, Italy, the Netherlands, Portugal and Spain) using daily data for the period 1999-2014. As in Beetsma et al. (2013), it uses newspaper coverage of macro news as a proxy for the way investors interpret news releases, which is a key factor determining their response. However, unlike that study, it models both mean and volatility spillovers, and it controls for the global financial crisis by allowing for exogenous financial shocks proxied by the VIX. The econometric analysis is based on the estimation of a VAR-GARCH $(1,1)$ model with a BEKK representation which is ideally suited to testing for both mean and volatility linkages between macro news and bond spreads.

The results can be summarized as follows. Negative news have significant positive effects on yield spreads in all GIIPS countries but Italy before September 2008; markets respond more to negative news, and their reaction has increased during the recent financial crisis. News volatility has a significant impact on yield spreads volatility, the effects being more pronounced in the case of negative news and bigger in the most recent crisis period, especially in the GIIPS countries. The exogenous factor considered, i.e. stock market returns, has the expected negative effect on 
yield spreads. Finally, the conditional correlations between yield spreads and negative news are significant and positive, and their increase in absolute value during the financial crisis (especially in the GIIPS countries) indicates a higher sensitivity of yield spreads to negative releases.

Overall, our findings confirm the important role played by press coverage of macro news in determining sovereign bond yields. Although mean spillovers had already been examined by Beetsma et al. (2013), our analysis provides new evidence on the existence of causality linkages between news volatility and yield spread volatility. This represents new evidence on the role played by uncertainty (as proxied by the conditional volatility) in this context; of particular interest is the finding that the latter have become even more responsive to the former during the recent financial crisis: the linkages between real sector news and financial markets have clearly become stronger in the euro area in the new financial environment (especially for the peripheral members of EMU), which should be taken into account in the debate on EU-wide macroprudential regulations.

\section{Acknowledgments}

We would like to thank seminar participants at the University College Dublin; Zeppelin University, Friedrichshafen; National Bank of Serbia; the Editor (Chris Adcock) and two anonymous referees for very useful comments and suggestions.

\section{Disclosure statement}

No potential conflict of interest was reported by the authors.

\section{Notes}

1. Caporale, Spagnolo, and Spagnolo (2016) focus instead on the effects on stock returns in eight countries belonging to the euro area and find that positive (negative) news have significant positive (negative) effects in all cases.

2. The model is based on the GARCH(1,1)-BEKK representation proposed by Engle and Kroner (1995).

3. These variables are treated as exogenous in order to obtain a system of equations of manageable dimensions.

4. The parameter $\left(a_{21}\right)$ in Equation (3) measures the causality effect of positive (negative) news volatility, whereas $\left(a_{21}+a_{21}^{*}\right)$ measures the possible effect of the 2008 financial crises.

5. Neutral and mixed news, which have been found not to be significant in previous studies, have not been considered given the aim of this paper.

6. Joint restrictions (iii) and (iv) are tested by means of the Wald test.

7. A positive $\beta_{12}$ implies that an increase in the number of negative news headlines widens the yield spread.

8. Consistently with results reported by Birz and Lott (2011) for the US, we do not find any statistical significant evidence of reverse causality in neither the first nor second moment.

9. The estimation of a day-of-the-week dummy did not provide evidence of any such effects (these additional results are not reported in the paper).

10. This is plausible, since news surprises can only be constructed on the relatively infrequent announcement days (such a series would contain several zeroes), whilst media coverage is daily.

11. The null hypothesis of a constant correlation has been tested using the Engle and Sheppard (2001) likelihood ratio test, and is rejected in all cases.

\section{References}

Altavilla, C., D. Giannone, and M. Modugno. 2013. "The Low Frequency Effects of Macroeconomic News on Government Bond Yields", mimeo.

Andersen, T. G., T. Bollerslev, F. X. Diebold, and C. Vega. 2005. "Real-time Price Discovery in Stock, Bond and Foreign Exchange Markets.” NBER Working Paper no. 11312. 
Andersson, M., L. J. Hansen, and S. Sebestyen. 2006. "Which News Moves the Euro Area Bond Market?" Working Paper no. 631, European Central Bank.

Andritzky, J. R., G. J. Bannister, and N. T. Tamirisa. 2005. “The Impact of Macroeconomic Announcements on Emerging Market Bonds." IMF Working Paper, WP/05/83.

Antweiler, W., and M. Z. Frank. 2004. "Is All That Talk Just Noise? The Information Content of Internet Stock Message Boards." Journal of Finance 59: 1259-1294.

Balduzzi, P., E. J. Elton, and T. C. Green. 2001. "Economic News and Bond Prices: Evidence from the US Treasury Market." Journal of Financial and Quantitative Analysis 36: 523-543.

Beetsma, R., M. Giuliodori, F. de Jong, and D. Widijanto. 2013. "Spread the News: The Impact of News on the European Sovereign Bond Markets During the Crisis." Journal of International Money and Finance 34: 83-101.

Birz, G., and J. R. Lott. 2011. "The Effect of Macroeconomic News on Stock Returns: New Evidence from Newspaper Coverage." Journal of Banking and Finance 35: 2791-2800.

Brenner, M., P. Pasquariello, and M. Subrahmanyam. 2009. "On the Volatility and Comovemenr of U.S. Financial Markets Around Macroeconomic News Announcements.” Mimeo, Stern School of Business, New York University.

Bollerslev, T., and J. M. Wooldridge. 1992. "Quasi-maximum Likelihood Estimation and Inference in Dynamic Models with Time-varying Covariances." Econometric Reviews 11: 143-172.

Boffelli, S., and G. Urga. 2015. "Macroannouncements, Bond Auctions and Rating Actions in the European Government Bond Spreads." Journal of International Money and Finance 53: 148-173.

Campbell, J. Y., S. J. Grossman, and J. Wang. 1993. "Trading Volume and Serial Correlation in Stock Returns." Quarterly Journal of Economics 108: 905-939.

Caporale, G. M., F. Spagnolo, and N. Spagnolo. 2016. "Macro News and Stock Returns in the Euro Area: A VARGARCH-in-Mean Analysis." International Review of Financial Analysis 45: 180-188.

Coval, J. D., and T. Shumway. 2001. "Is Sound Just Noise?.” Journal of Finance 56: 1887-1910.

De Grauwe, P., and Y. Ji. 2013. "Self-fulfilling Crises in the Eurozone: An Empirical Test." Journal of International Money and Finance 34: 15-36.

De Long, J. B., A. Shleifer, L. H. Summers, and R. J. Waldmann. 1990. "Noise Trader Risk in Financial Markets." Journal of Political Economy 98: 703-738.

Engle, R. F., and K. F. Kroner. 1995. "Multivariate Simultaneous Generalized ARCH.” Econometric Theory 11: $122-150$.

Engle, R. F., and K. Sheppard. 2001. "Theoretical and Empirical Properties of Dynamic Conditional Correlation Multivariate GARCH.” Working Paper No. 2001-15, University of California, San Diego.

Fang, L., and J. Peress. 2009. "Media Coverage and the Cross-section of Stock Returns." Journal of Finance 64 (5): 2023-2052.

Gürkaynak, R. S., B. Sack, and E. Swanson. 2005. "The Sensitivity of Long-Term Interest Rates to Economic News: Evidence and Implications for Macroeconomic Models." The American Economic Review 95 (1): 425-436.

Huang, J., and W. Kong. 2007. "Macroeconomic News Announcements and Corporate Bond Credit Spreads." Mimeo, Penn State University.

Jiang, G. J., I. Lo, and G. Valente. 2013. "High Frequency Trading Around Macroeconomic News Announcements: Evidence from the US Treasury Market." Mimeo, Bank of Canada.

Liebermann, J.. 2011. “The Impact of Macroeconomic News on Bond Yields: (In)stabilities Over Time and Relative Importance." 07/RT/11, Central Bank of Ireland.

Ljung, G. M., and G. E. P. Box. 1978. “On a Measure of Lack of Fit in Time Series Models.” Biometrika 65: 297-303.

Robitaille, P., and J. Roush. 2006. "How Do FOMC Actions and U.S. Macroeconomic Data Announcements Move Brazilian Sovereign Yield Spreads and Stock Prices?.” International Finance Discussion Paper No. 868, Board of Governors of the Federal Reserve System.

Saka, O., A.-M. Fuertes, and E. Klotychou. 2015. "ECB Policy and Eurozone Fragility: Was De Grauwe Right?” Journal of International Money and Finance 54: 168-185.

Tetlock, P. C. 2007. "Giving Content to Investor Sentiment: The Role of Media in the Stock Market." Journal of Finance 62 (3): 1139-1168.

Tetlock, P. C., M. Saar-Tsechansky, and S. Macskassy. 2008. "More Than Words: Quantifying Language to Measure Firms' fundamentals." Journal of Finance 63: 1437-1467. 


\section{Appendix}

Table A1. Estimated VAR-GARCH(1,1) model for Belgium.

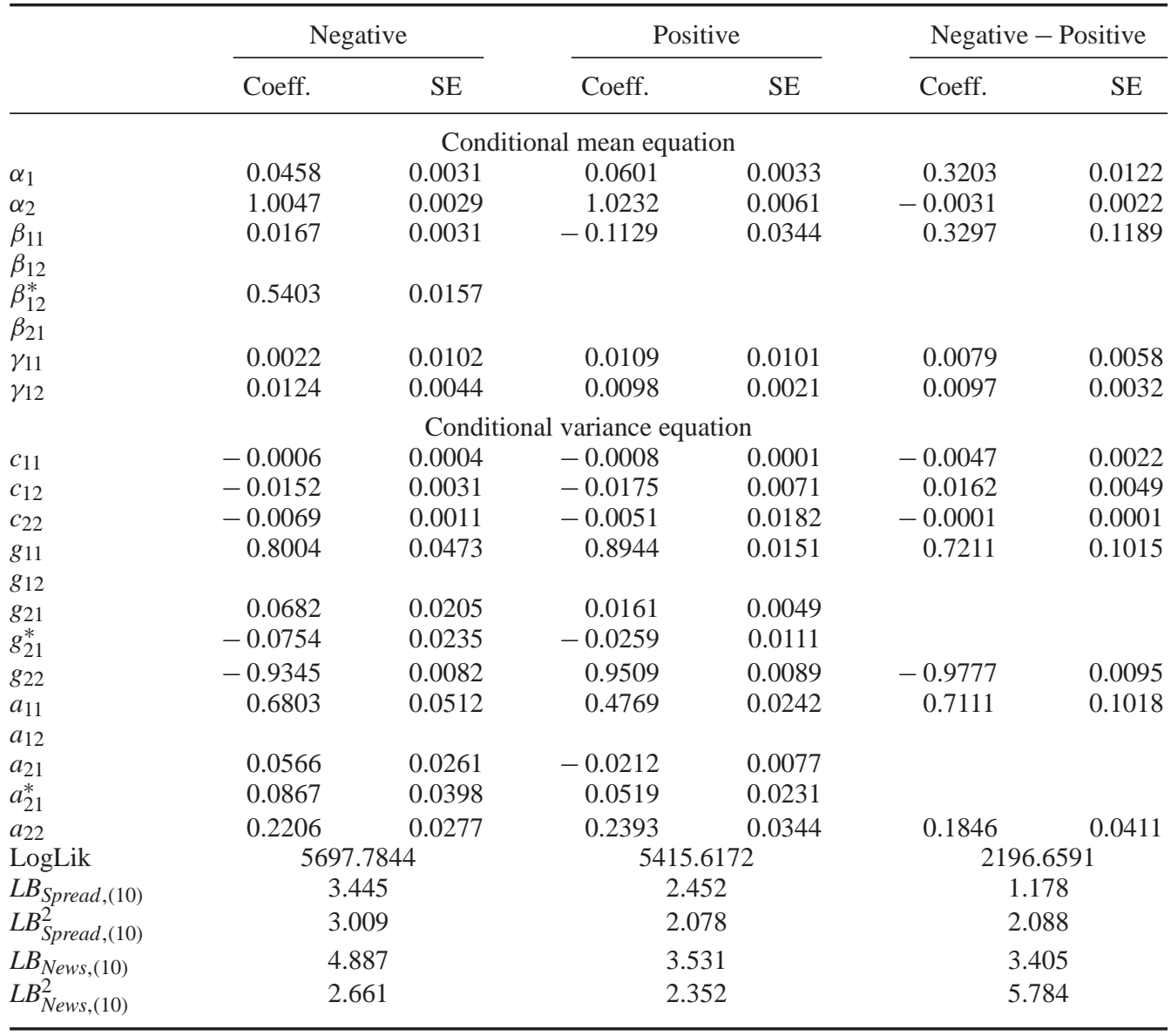

The number of positive (negative) newspaper headlines index is defined as follows: Positive(Negative)NewsIndex $=$ $\ln [e+$ domesticpositive(negative)news + internationalpositive(negative)news]. Standard errors (SE) are calculated using the quasi-maximum likelihood method of Bollerslev and Wooldridge (1992), which is robust to the distribution of the underlying residuals. The parameters not statistically significant at the $5 \%$ level are not reported. $L B_{\text {Spread }(10)}$ and $L B_{\text {Spread (10) }}^{2}$ are the Ljung-Box test (1978) of significance of autocorrelations of 10 lags in the standardized and standardized squared residuals, respectively. The parameter $\beta_{12}$ measures the causality effect of positive (negative) news on the yield spread, whereas $a_{21}$ measures the causality-in-variance effect of positive (negative) news. The effect of the 2008 financial crisis on the yield spread is measured by $\left(\beta_{12}+\beta_{12}^{*}\right)$, whereas $\left(a_{21}+a_{21}^{*}\right)$ captures the effects on spread volatilities. The covariance stationarity condition is satisfied by all the estimated models, all the eigenvalues of $A_{11} \otimes A_{11}+G_{11} \otimes G_{11}$ being less than one in modulus. Note that in the conditional variance equation the sign of the parameters cannot be determined. 
Table A2. Estimated VAR-GARCH $(1,1)$ model for France.

\begin{tabular}{|c|c|c|c|c|c|c|}
\hline & \multicolumn{2}{|c|}{ Negative } & \multicolumn{2}{|c|}{ Positive } & \multicolumn{2}{|c|}{ Negative - positive } \\
\hline & Coeff. & SE & Coeff. & SE & Coeff. & SE \\
\hline \multicolumn{7}{|c|}{ Conditional mean equation } \\
\hline$\alpha_{1}$ & 0.0511 & 0.0032 & 0.0509 & 0.0029 & 0.0467 & 0.0005 \\
\hline$\alpha_{2}$ & 1.0654 & 0.0198 & 1.0662 & 0.0165 & 0.0287 & 0.0182 \\
\hline$\beta_{11}$ & -0.0711 & 0.0076 & 0.0244 & 0.0108 & 0.0443 & 0.0031 \\
\hline$\beta_{12}$ & -0.0035 & 0.0012 & & & 0.0027 & 0.0011 \\
\hline$\beta_{12}^{*}$ & 0.2899 & 0.0185 & & & 0.0972 & 0.0147 \\
\hline \multicolumn{7}{|l|}{$\beta_{21}$} \\
\hline$\gamma_{11}$ & 0.0094 & 0.0113 & 0.0187 & 0.0206 & 0.0101 & 0.0212 \\
\hline$\gamma_{12}$ & 0.0109 & 0.0042 & 0.0102 & 0.0039 & 0.0093 & 0.0044 \\
\hline \multicolumn{7}{|c|}{ Conditional variance equation } \\
\hline$c_{11}$ & -0.0015 & 0.0005 & 0.0011 & 0.0008 & 0.0015 & 0.0002 \\
\hline$c_{12}$ & 0.0001 & 0.0166 & -0.0073 & 0.0288 & 0.0076 & 0.0062 \\
\hline$c_{22}$ & 0.0221 & 0.0061 & 0.0244 & 0.0091 & 0.0355 & 0.0072 \\
\hline$g_{11}$ & -0.8774 & 0.0315 & 0.8926 & 0.0188 & -0.7452 & 0.0376 \\
\hline \multicolumn{7}{|l|}{$g_{12}$} \\
\hline$g_{21}$ & & & 0.0171 & 0.0019 & -0.0364 & 0.0111 \\
\hline$g_{21}^{*}$ & & & -0.0531 & 0.0188 & 0.0507 & 0.0188 \\
\hline$g_{22}$ & -0.9806 & 0.0085 & 0.9877 & 0.0035 & -0.9829 & 0.0055 \\
\hline$a_{11}$ & 0.5309 & 0.0489 & 0.4637 & 0.0356 & 0.6905 & 0.0322 \\
\hline \multicolumn{7}{|l|}{$a_{12}$} \\
\hline$a_{21}$ & & & 0.0010 & 0.0002 & -0.1207 & 0.0499 \\
\hline$a_{21}^{*}$ & & & 0.1199 & 0.0474 & & \\
\hline$a_{22}$ & 0.1966 & 0.0201 & 0.1911 & 0.0274 & 0.1816 & 0.0193 \\
\hline LogLik & \multicolumn{2}{|c|}{4876.5522} & \multicolumn{2}{|c|}{4487.5382} & \multicolumn{2}{|c|}{2067.6741} \\
\hline$L B_{\text {Spread },(10)}$ & \multicolumn{2}{|c|}{3.683} & \multicolumn{2}{|c|}{3.342} & \multicolumn{2}{|c|}{4.663} \\
\hline$L B_{\text {Spread,(10) }}^{2}$ & \multicolumn{2}{|c|}{4.752} & \multicolumn{2}{|c|}{3.866} & \multicolumn{2}{|c|}{3.995} \\
\hline$L B_{\text {News },(10)}$ & \multirow{2}{*}{\multicolumn{2}{|c|}{$\begin{array}{l}4.339 \\
3.072\end{array}$}} & \multicolumn{2}{|c|}{3.622} & \multicolumn{2}{|c|}{4.006} \\
\hline$L B_{\text {News, (10) }}^{2}$ & & & \multicolumn{2}{|c|}{2.055} & \multicolumn{2}{|c|}{3.442} \\
\hline
\end{tabular}


18 G.M. Caporale et al.

Table A3. Estimated VAR-GARCH $(1,1)$ model for Greece.

\begin{tabular}{|c|c|c|c|c|c|c|}
\hline & \multicolumn{2}{|c|}{ Negative } & \multicolumn{2}{|c|}{ Positive } & \multicolumn{2}{|c|}{ Negative - positive } \\
\hline & Coeff. & SE & Coeff. & SE & Coeff. & SE \\
\hline \multicolumn{7}{|c|}{ Conditional mean equation } \\
\hline$\alpha_{1}$ & 0.0767 & 0.0011 & 0.0297 & 0.0016 & 0.2243 & 0.0015 \\
\hline$\alpha_{2}$ & 1.0086 & 0.0001 & 1.0039 & 0.0001 & 0.0046 & 0.0015 \\
\hline$\beta_{11}$ & 0.1034 & 0.0339 & 0.0816 & 0.0098 & & \\
\hline$\beta_{12}$ & 0.0688 & 0.0096 & & & 0.0076 & 0.0033 \\
\hline$\beta_{12}^{*}$ & 6.6712 & 0.0236 & & & 1.1121 & 0.1446 \\
\hline \multicolumn{7}{|l|}{$\beta_{21}$} \\
\hline$\gamma_{11}$ & 0.0221 & 0.0301 & 0.0412 & 0.0387 & 0.0447 & 0.0301 \\
\hline$\gamma_{12}$ & 0.1209 & 0.0321 & 0.1134 & 0.0512 & 0.0995 & 0.0419 \\
\hline \multicolumn{7}{|c|}{ Conditional variance equation } \\
\hline$c_{11}$ & -0.0012 & 0.0004 & 0.0021 & 0.0003 & 0.0036 & 0.0005 \\
\hline$c_{12}$ & 0.0001 & 0.0001 & -0.0001 & 0.0001 & 0.0077 & 0.0036 \\
\hline$c_{22}$ & 0.0001 & 0.0001 & 0.0001 & 0.0001 & 0.0001 & 0.0001 \\
\hline$g_{11}$ & 0.6877 & 0.0142 & 0.9611 & 0.0442 & 0.9811 & 0.0472 \\
\hline \multicolumn{7}{|l|}{$g_{12}$} \\
\hline$g_{21}$ & 0.0158 & 0.0057 & 0.0305 & 0.0121 & 0.0032 & 0.0015 \\
\hline$g_{21}^{*}$ & -0.0321 & 0.0077 & -0.0188 & 0.0081 & -0.0047 & 0.0019 \\
\hline$g_{22}$ & 0.9212 & 0.0243 & 0.4402 & 0.1332 & 0.9899 & 0.0061 \\
\hline$a_{11}$ & 0.8113 & 0.0355 & -0.3823 & 0.1401 & -0.2887 & 0.1488 \\
\hline \multicolumn{7}{|l|}{$a_{12}$} \\
\hline$a_{21}$ & 0.0291 & 0.0116 & 0.0175 & 0.0099 & 0.0113 & 0.0064 \\
\hline$a_{21}^{*}$ & 0.0388 & 0.0075 & -0.0026 & 0.0011 & -0.0072 & 0.0033 \\
\hline$a_{22}$ & 0.1605 & 0.0288 & 0.4221 & 0.1612 & 0.1304 & 0.0163 \\
\hline LogLik & \multicolumn{2}{|c|}{7345.3221} & \multicolumn{2}{|c|}{6698.3988} & \multicolumn{2}{|c|}{5785.7763} \\
\hline$L B_{\text {Spread },(10)}$ & \multicolumn{2}{|c|}{5.087} & \multicolumn{2}{|c|}{4.222} & \multicolumn{2}{|c|}{3.088} \\
\hline$L B_{\text {Spread,(10) }}^{2}$ & \multicolumn{2}{|c|}{4.991} & \multicolumn{2}{|c|}{3.943} & \multicolumn{2}{|c|}{2.117} \\
\hline$L B_{\text {News, (10) }}$ & \multirow{2}{*}{\multicolumn{2}{|c|}{$\begin{array}{l}3.007 \\
4.105\end{array}$}} & \multicolumn{2}{|c|}{3.853} & \multicolumn{2}{|c|}{3.442} \\
\hline$L B_{\text {News, (10) }}^{2}$ & & & \multicolumn{2}{|c|}{4.218} & \multicolumn{2}{|c|}{2.885} \\
\hline
\end{tabular}


Table A4. Estimated VAR-GARCH $(1,1)$ model for Ireland.

\begin{tabular}{|c|c|c|c|c|c|c|}
\hline & \multicolumn{2}{|c|}{ Negative } & \multicolumn{2}{|c|}{ Positive } & \multicolumn{2}{|c|}{ Negative - positive } \\
\hline & Coeff. & SE & Coeff. & SE & Coeff. & SE \\
\hline \multicolumn{7}{|c|}{ Conditional mean equation } \\
\hline$\alpha_{1}$ & -0.5732 & 0.0235 & -0.0301 & 0.0143 & -0.0289 & 0.0056 \\
\hline$\alpha_{2}$ & 1.0009 & 0.0001 & 1.0048 & 0.0002 & 0.0052 & 0.0011 \\
\hline$\beta_{11}$ & 0.0975 & 0.0112 & 0.0765 & 0.0224 & 0.0601 & 0.0067 \\
\hline$\beta_{12}$ & 0.7344 & 0.0399 & & & & \\
\hline$\beta_{12}^{*}$ & 0.8816 & 0.1229 & & & 0.3331 & 0.1442 \\
\hline \multicolumn{7}{|l|}{$\beta_{21}$} \\
\hline$\gamma_{11}$ & 0.0654 & 0.0366 & 0.1101 & 0.0474 & 0.0771 & 0.0449 \\
\hline$\gamma_{12}$ & 0.1134 & 0.0476 & 0.1224 & 0.0416 & 0.1005 & 0.0397 \\
\hline \multicolumn{7}{|c|}{ Conditional variance equation } \\
\hline$c_{11}$ & -0.0028 & 0.0008 & -0.0025 & 0.0011 & 0.0012 & 0.0004 \\
\hline$c_{12}$ & -0.0001 & 0.0001 & 0.0061 & 0.0022 & -0.0545 & 0.0112 \\
\hline$c_{22}$ & -0.0001 & 0.0001 & 0.0001 & 0.0302 & -0.0001 & 0.0331 \\
\hline$g_{11}$ & -0.8911 & 0.0199 & -0.8409 & 0.0398 & -0.8431 & 0.0797 \\
\hline \multicolumn{7}{|l|}{$g_{12}$} \\
\hline$g_{21}$ & -0.0189 & 0.0071 & -0.0361 & 0.0088 & 0.0721 & 0.0301 \\
\hline$g_{21}^{*}$ & 0.0231 & 0.0096 & -0.0696 & 0.0122 & -0.0384 & 0.0108 \\
\hline$g_{22}$ & 0.8332 & 0.0702 & 0.8882 & 0.0305 & 0.6208 & 0.0887 \\
\hline$a_{11}$ & 0.5087 & 0.0772 & 0.5534 & 0.0875 & 0.2663 & 0.1109 \\
\hline \multicolumn{7}{|l|}{$a_{12}$} \\
\hline$a_{21}$ & -0.0499 & 0.0105 & -0.0118 & 0.0031 & 0.1523 & 0.0211 \\
\hline$a_{21}^{*}$ & 0.1213 & 0.0338 & -0.0244 & 0.0176 & -0.0616 & 0.0223 \\
\hline$a_{22}$ & 0.4453 & 0.0996 & -0.2732 & 0.0522 & 0.1886 & 0.0481 \\
\hline LogLik & \multicolumn{2}{|c|}{7865.2213} & \multicolumn{2}{|c|}{6714.0952} & \multicolumn{2}{|c|}{1926.4432} \\
\hline$L B_{\text {Spread },(10)}$ & \multicolumn{2}{|c|}{2.003} & \multicolumn{2}{|c|}{4.337} & \multicolumn{2}{|c|}{4.442} \\
\hline$L B_{\text {Spread,(10) }}^{2}$ & \multicolumn{2}{|c|}{4.661} & \multicolumn{2}{|c|}{2.923} & \multicolumn{2}{|c|}{4.006} \\
\hline$L B_{\text {News },(10)}$ & \multirow{2}{*}{\multicolumn{2}{|c|}{$\begin{array}{l}3.009 \\
3.870\end{array}$}} & \multicolumn{2}{|c|}{1.009} & \multicolumn{2}{|c|}{3.775} \\
\hline$L B_{\text {News, (10) }}^{2}$ & & & \multicolumn{2}{|c|}{3.774} & \multicolumn{2}{|c|}{2.881} \\
\hline
\end{tabular}


20 G.M. Caporale et al.

Table A5. Estimated VAR-GARCH(1,1) model for Italy.

\begin{tabular}{|c|c|c|c|c|c|c|}
\hline & \multicolumn{2}{|c|}{ Negative } & \multicolumn{2}{|c|}{ Positive } & \multicolumn{2}{|c|}{ Negative - positive } \\
\hline & Coeff. & SE & Coeff. & SE & Coeff. & SE \\
\hline \multicolumn{7}{|c|}{ Conditional mean equation } \\
\hline$\alpha_{1}$ & 0.1756 & 0.0446 & 0.2816 & 0.0109 & 0.2245 & 0.0125 \\
\hline$\alpha_{2}$ & 1.0026 & 0.0015 & 1.0099 & 0.0033 & 0.0544 & 0.0089 \\
\hline$\beta_{11}$ & -0.3054 & 0.0221 & -0.0231 & 0.0107 & -0.3765 & 0.0128 \\
\hline$\beta_{12}$ & & & -0.0266 & 0.0132 & & \\
\hline$\beta_{12}^{*}$ & 1.7216 & 0.0457 & & & 0.2805 & 0.1118 \\
\hline \multicolumn{7}{|l|}{$\beta_{21}$} \\
\hline$\gamma_{11}$ & 0.1009 & 0.0698 & 0.0983 & 0.0557 & 0.0819 & 0.0477 \\
\hline$\gamma_{12}$ & 0.1065 & 0.0503 & 0.1076 & 0.0321 & 0.0993 & 0.0451 \\
\hline \multicolumn{7}{|c|}{ Conditional variance equation } \\
\hline$c_{11}$ & -0.0015 & 0.0003 & 0.0019 & 0.0006 & 0.0061 & 0.0019 \\
\hline$c_{12}$ & -0.0313 & 0.0077 & -0.0162 & 0.0122 & -0.0027 & 0.0101 \\
\hline$c_{22}$ & -0.0001 & -0.0001 & 0.0035 & 0.0226 & -0.0211 & 0.0087 \\
\hline$g_{11}$ & 0.7886 & 0.0441 & 0.8708 & 0.0064 & 0.8224 & 0.0719 \\
\hline \multicolumn{7}{|l|}{$g_{12}$} \\
\hline$g_{21}$ & -0.1206 & 0.0447 & 0.0167 & 0.0042 & 0.0523 & 0.0105 \\
\hline$g_{21}^{*}$ & 0.1287 & 0.05001 & -0.0087 & 0.0021 & -0.0698 & 0.0129 \\
\hline$g_{22}$ & 0.8109 & 0.1222 & 0.9508 & 0.0131 & 0.9778 & 0.0064 \\
\hline$a_{11}$ & -0.2277 & 0.0288 & 0.5599 & 0.0977 & 0.5442 & 0.1208 \\
\hline \multicolumn{7}{|l|}{$a_{12}$} \\
\hline$a_{21}$ & -0.4222 & 0.0674 & -0.0091 & 0.0011 & -0.0597 & 0.0223 \\
\hline$a_{21}^{*}$ & -0.0144 & 0.0065 & -0.0117 & 0.0055 & 0.0808 & 0.0202 \\
\hline$a_{22}$ & 0.0618 & 0.0397 & -0.2904 & 0.0558 & 0.1834 & 0.0199 \\
\hline LogLik & \multicolumn{2}{|c|}{4121.0168} & \multicolumn{2}{|c|}{4963.4543} & \multicolumn{2}{|c|}{2654.1129} \\
\hline$L B_{\text {Spread },(10)}$ & \multicolumn{2}{|c|}{4.975} & \multicolumn{2}{|c|}{3.099} & \multicolumn{2}{|c|}{3.774} \\
\hline$L B_{\text {Spread },(10)}^{2}$ & \multicolumn{2}{|c|}{4.007} & \multicolumn{2}{|c|}{4.771} & \multicolumn{2}{|c|}{2.184} \\
\hline$L B_{\text {News, (10) }}$ & \multirow{2}{*}{\multicolumn{2}{|c|}{$\begin{array}{l}4.238 \\
3.664\end{array}$}} & \multicolumn{2}{|c|}{3.074} & \multicolumn{2}{|c|}{3.066} \\
\hline$L B_{N e w s,(10)}^{2}$ & & & \multicolumn{2}{|c|}{3.333} & \multicolumn{2}{|c|}{3.805} \\
\hline
\end{tabular}


Table A6. Estimated VAR-GARCH $(1,1)$ model for the Netherlands.

\begin{tabular}{|c|c|c|c|c|c|c|}
\hline & \multicolumn{2}{|c|}{ Negative } & \multicolumn{2}{|c|}{ Positive } & \multicolumn{2}{|c|}{ Negative - positive } \\
\hline & Coeff. & SE & Coeff. & SE & Coeff. & SE \\
\hline \multicolumn{7}{|c|}{ Conditional mean equation } \\
\hline$\alpha_{1}$ & 0.1187 & 0.0107 & 0.1876 & 0.0342 & 0.1412 & 0.0087 \\
\hline$\alpha_{2}$ & 1.0187 & 0.0067 & 1.0108 & 0.0044 & -0.0091 & 0.0063 \\
\hline$\beta_{11}$ & 0.0567 & 0.0106 & 0.0981 & 0.0103 & -0.1845 & 0.0037 \\
\hline$\beta_{12}$ & & & -0.0792 & 0.0301 & & \\
\hline$\beta_{12}^{*}$ & 0.1412 & 0.0139 & & & & \\
\hline \multicolumn{7}{|l|}{$\beta_{21}$} \\
\hline$\gamma_{11}$ & 0.1143 & 0.0782 & 0.0671 & 0.0448 & 0.0982 & 0.0683 \\
\hline$\gamma_{12}$ & 0.1139 & 0.0577 & 0.0983 & 0.0466 & 0.0874 & 0.0336 \\
\hline \multicolumn{7}{|c|}{ Conditional variance equation } \\
\hline$c_{11}$ & -0.0039 & 0.0005 & 0.0040 & 0.0011 & -0.0027 & 0.0009 \\
\hline$c_{12}$ & 0.0166 & 0.0099 & -0.0133 & 0.0028 & 0.0067 & 0.0011 \\
\hline$c_{22}$ & 0.0002 & 0.0001 & 0.0001 & 0.0001 & 0.0212 & 0.0088 \\
\hline$g_{11}$ & -0.7288 & 0.0433 & -0.7366 & 0.0447 & 0.89124 & 0.0332 \\
\hline \multicolumn{7}{|l|}{$g_{12}$} \\
\hline$g_{21}$ & 0.1331 & 0.0111 & -0.1301 & 0.0612 & 0.0454 & 0.0199 \\
\hline$g_{21}^{*}$ & 0.0704 & 0.0201 & 0.7225 & 0.2663 & 0.0612 & 0.0197 \\
\hline$g_{22}$ & 0.9845 & 0.0127 & 0.9822 & 0.0144 & 0.9705 & 0.0224 \\
\hline$a_{11}$ & 0.7709 & 0.0443 & 0.7122 & 0.0408 & 0.4885 & 0.0661 \\
\hline \multicolumn{7}{|l|}{$a_{12}$} \\
\hline$a_{21}$ & -0.0977 & 0.0337 & 0.0717 & 0.0301 & -0.0981 & 0.0402 \\
\hline$a_{21}^{*}$ & 0.5722 & 0.1009 & -0.4992 & 0.1221 & -0.1209 & 0.0443 \\
\hline$a_{22}$ & 0.1662 & 0.0309 & 0.1553 & 0.0331 & 0.2335 & 0.0667 \\
\hline LogLik & \multicolumn{2}{|c|}{7854.7754} & \multicolumn{2}{|c|}{7229.0763} & \multicolumn{2}{|c|}{5723.7669} \\
\hline$L B_{\text {Spread },(10)}$ & \multicolumn{2}{|c|}{4.771} & \multicolumn{2}{|c|}{3.984} & \multicolumn{2}{|c|}{3.632} \\
\hline$L B_{\text {Spread,(10) }}^{2}$ & \multicolumn{2}{|c|}{4.442} & \multicolumn{2}{|c|}{4.119} & \multicolumn{2}{|c|}{4.223} \\
\hline$L B_{\text {News },(10)}$ & \multicolumn{2}{|c|}{3.634} & \multicolumn{2}{|c|}{2.878} & \multicolumn{2}{|c|}{4.009} \\
\hline$L B_{\text {News, (10) }}^{2}$ & \multicolumn{2}{|c|}{3.772} & \multicolumn{2}{|c|}{3.442} & \multicolumn{2}{|c|}{4.829} \\
\hline
\end{tabular}


22 G.M. Caporale et al.

Table A7. Estimated VAR-GARCH(1,1) model for Portugal.

\begin{tabular}{|c|c|c|c|c|c|c|}
\hline & \multicolumn{2}{|c|}{ Negative } & \multicolumn{2}{|c|}{ Positive } & \multicolumn{2}{|c|}{ Negative - positive } \\
\hline & Coeff. & SE & Coeff. & SE & Coeff. & SE \\
\hline \multicolumn{7}{|c|}{ Conditional mean equation } \\
\hline$\alpha_{1}$ & -0.6032 & 0.0323 & 0.1923 & 0.0108 & 0.1077 & 0.0097 \\
\hline$\alpha_{2}$ & 1.0037 & 0.0001 & 1.0061 & 0.0002 & 0.0091 & 0.0021 \\
\hline$\beta_{11}$ & 0.2412 & 0.0067 & 0.0222 & 0.0071 & 0.5013 & 0.0131 \\
\hline$\beta_{12}$ & 0.7345 & 0.0322 & -0.0406 & 0.0098 & & \\
\hline$\beta_{12}^{*}$ & 4.2016 & 0.0423 & & & 0.0923 & 0.0489 \\
\hline \multicolumn{7}{|l|}{$\beta_{21}$} \\
\hline$\gamma_{11}$ & 0.1009 & 0.7782 & 0.0671 & 0.0448 & 0.0982 & 0.0782 \\
\hline$\gamma_{12}$ & 0.3652 & 0.1446 & 0.1432 & 0.0609 & 0.0442 & 0.0139 \\
\hline \multicolumn{7}{|c|}{ Conditional variance equation } \\
\hline$c_{11}$ & -0.0039 & 0.0006 & 0.0036 & 0.0011 & -0.0015 & 0.007 \\
\hline$c_{12}$ & -0.0001 & 0.0001 & 0.0001 & 0.0001 & -0.0503 & 0.0033 \\
\hline$c_{22}$ & -0.0001 & 0.0001 & 0.0001 & 0.0001 & -0.0431 & 0.0109 \\
\hline$g_{11}$ & 0.7055 & 0.0101 & 0.7442 & 0.0221 & -0.6235 & 0.0347 \\
\hline \multicolumn{7}{|l|}{$g_{12}$} \\
\hline$g_{21}$ & -0.0933 & 0.0201 & 0.0278 & 0.0099 & & \\
\hline$g_{21}^{*}$ & 0.0477 & 0.0142 & -0.0763 & 0.0138 & & \\
\hline$g_{22}$ & -0.6213 & 0.0144 & -0.8477 & 0.0228 & 0.8231 & 0.0443 \\
\hline$a_{11}$ & 0.1699 & 0.0344 & 0.4771 & 0.0553 & 0.3241 & 0.0528 \\
\hline \multicolumn{7}{|l|}{$a_{12}$} \\
\hline$a_{21}$ & 0.0677 & 0.0332 & -0.0397 & 0.0109 & 0.0268 & 0.0077 \\
\hline$a_{21}^{*}$ & 0.0795 & 0.0228 & -0.0087 & 0.0001 & 0.0599 & 0.0105 \\
\hline$a_{22}$ & 0.3774 & 0.0624 & -0.0755 & 0.0236 & 0.0801 & 0.0057 \\
\hline LogLik & \multicolumn{2}{|c|}{9316.4421} & \multicolumn{2}{|c|}{8867.7444} & \multicolumn{2}{|c|}{1651.3129} \\
\hline$L B_{\text {Spread },(10)}$ & \multicolumn{2}{|c|}{4.112} & \multicolumn{2}{|c|}{4.231} & \multicolumn{2}{|c|}{3.772} \\
\hline$L B_{\text {Spread,(10) }}^{2}$ & \multicolumn{2}{|c|}{3.874} & \multicolumn{2}{|c|}{3.228} & \multicolumn{2}{|c|}{4.632} \\
\hline$L B_{\text {News },(10)}$ & \multirow{2}{*}{\multicolumn{2}{|c|}{$\begin{array}{l}4.546 \\
4.987\end{array}$}} & \multicolumn{2}{|c|}{3.112} & \multicolumn{2}{|c|}{3.771} \\
\hline$L B_{\text {News, (10) }}^{2}$ & & & \multicolumn{2}{|c|}{2.992} & \multicolumn{2}{|c|}{3.223} \\
\hline
\end{tabular}


Table A8. Estimated VAR-GARCH(1,1) model for Spain.

\begin{tabular}{|c|c|c|c|c|c|c|}
\hline & \multicolumn{2}{|c|}{ Negative } & \multicolumn{2}{|c|}{ Positive } & \multicolumn{2}{|c|}{ Negative - positive } \\
\hline & Coeff. & SE & Coeff. & SE & Coeff. & SE \\
\hline \multicolumn{7}{|c|}{ Conditional mean equation } \\
\hline$\alpha_{1}$ & 0.2699 & 0.1249 & 0.0123 & 0.0108 & 0.0189 & 0.0066 \\
\hline$\alpha_{2}$ & 1.0044 & 0.0001 & 1.0041 & 0.0005 & 0.0189 & 0.0046 \\
\hline$\beta_{11}$ & 0.0601 & 0.0128 & 0.2633 & 0.1213 & -0.0541 & 0.0189 \\
\hline$\beta_{12}$ & 0.0901 & 0.0229 & & & & \\
\hline$\beta_{12}^{*}$ & 2.1916 & 0.0542 & & & 0.5311 & 0.1291 \\
\hline \multicolumn{7}{|l|}{$\beta_{21}$} \\
\hline$\gamma_{11}$ & 0.4331 & 0.2401 & 0.3321 & 0.2448 & 0.0982 & 0.0782 \\
\hline$\gamma_{12}$ & 0.5219 & 0.2209 & 0.2361 & 0.0998 & 0.1192 & 0.0558 \\
\hline \multicolumn{7}{|c|}{ Conditional variance equation } \\
\hline$c_{11}$ & 0.0012 & 0.0003 & -0.0014 & 0.0003 & -0.0014 & 0.0003 \\
\hline$c_{12}$ & -0.0025 & 0.0007 & 0.0061 & 0.0019 & 0.0081 & 0.0012 \\
\hline$c_{22}$ & -0.0001 & 0.0011 & -0.0001 & 0.0001 & 0.0156 & 0.0098 \\
\hline$g_{11}$ & -0.6887 & 0.0128 & 0.6128 & 0.0448 & 0.8782 & 0.0477 \\
\hline \multicolumn{7}{|l|}{$g_{12}$} \\
\hline$g_{21}$ & -0.0018 & 0.0006 & 0.0243 & 0.0011 & 0.0409 & 0.0104 \\
\hline$g_{21}^{*}$ & 0.0257 & 0.0066 & 0.0101 & 0.0002 & -0.1201 & 0.0277 \\
\hline$g_{22}$ & 0.9754 & 0.0012 & -0.9487 & 0.0113 & 0.9809 & 0.0034 \\
\hline$a_{11}$ & 0.7844 & 0.0211 & 0.8679 & 0.0388 & -0.5133 & 0.0575 \\
\hline \multicolumn{7}{|l|}{$a_{12}$} \\
\hline$a_{21}$ & 0.0866 & 0.0045 & 0.0834 & 0.0022 & 0.0377 & 0.0092 \\
\hline$a_{21}^{*}$ & 0.1123 & 0.0299 & -0.0196 & 0.0033 & 0.0262 & 0.0078 \\
\hline$a_{22}$ & 0.1699 & 0.0331 & -0.1301 & 0.0621 & 0.1801 & 0.0301 \\
\hline LogLik & \multicolumn{2}{|c|}{7324.6645} & \multicolumn{2}{|c|}{6834.2153} & \multicolumn{2}{|c|}{1601.3312} \\
\hline$L B_{\text {Spread },(10)}$ & \multicolumn{2}{|c|}{4.774} & \multicolumn{2}{|c|}{4.019} & \multicolumn{2}{|c|}{3.221} \\
\hline$L B_{\text {Spread,(10) }}^{2}$ & \multicolumn{2}{|c|}{4.008} & \multicolumn{2}{|c|}{3.341} & \multicolumn{2}{|c|}{4.529} \\
\hline$L B_{\text {News },(10)}$ & \multirow{2}{*}{\multicolumn{2}{|c|}{$\begin{array}{l}3.774 \\
2.663\end{array}$}} & \multicolumn{2}{|c|}{3.224} & \multicolumn{2}{|c|}{4.116} \\
\hline$L B_{\text {News, (10) }}^{2}$ & & & \multicolumn{2}{|c|}{3.164} & \multicolumn{2}{|c|}{3.044} \\
\hline
\end{tabular}

